\title{
The Importance of Teacher Performance: Case Study of Elementary School in West Balikpapan
}

\author{
Misna Ariani ${ }^{1}$, Desi $^{2}$ \\ Faculty of Economics, Balikpapan University, Indonesia \\ ${ }^{1}$ dinarariani@yahoo.com \\ ${ }^{2}$ misna.uniba@gmail.com
}

\begin{abstract}
Improving and maintaining qualified teachers is very important to provide quality education in schools, especially in primary schools. The quality of teachers is seen from teacher performance that is influenced by compensation, work environment, and work motivation. Teachers' performance can produce quality students, making it easy to pursue a quality secondary school. Effective and efficient teaching and learning process can produce high achieving students. Therefore, it is important to consider all the factors that affect the performance of teachers. This study aims to review the effect of these factors to assess teacher performance. The method used to determine the sample is proportional random sampling. This study used 88 teachers were who samples from 20 public elementary schools in West Balikpapan. The result of the research is compensation, work environment, work motivation has a significant and proven effect that work environment has dominant influence to teacher performance.
\end{abstract}

Keywords — performance, compensation, work environment, work motivation, primary school.

\section{INTRODUCTION}

In Indonesia, teachers get the title of a hero without services. The Government of Indonesia has issued the Constitution of the Republic of Indonesia No.2 of 1989 article 4, which is about National Education function to develop the ability and form the character and civilization of dignified nation in order to educate the life of the nation, aiming for the development of the potential of learners to become human beings who believe and trust in God Almighty, noble, healthy, knowledgeable, capable, creative, independent, and become a democratic, responsible citizen. To achieve these educational granules needs to be preceded by an adequate educational process. The effort to form and develop the ability of learners needed Human Resources (teachers), namely to foster and develop a better school education.

Satisfied teachers are generally more productive and may influence student achievement [15]. Furthermore, if teachers are satisfied with their work, they will develop and maintain a high level of performance. Teaching and learning process becomes more efficient and effective so that it can produce students who have high competitive [44].

Meanwhile, reference [25] in his research on job satisfaction recommends that the salaries of workers should be paid immediately and the promotion of workers should be in accordance with the raise they receive. Therefore, job satisfaction through financial rewards has a greater impact or effect on nonfinancial benefits on the performance of primary school teachers.

On the other hand, [14] argues that performance is output. According to him to gives awards to members of an organization, then the need for a provision for performance criteria. Similarly, [4] say that performance is a result achieved among staff. While [9] says that staff performance is behavioral and should be distinguished from the results because they can do it.

Based on some of these research results, the teacher performance study that is influenced by compensation, work environment, work motivation is still relevant to be studied. The performance of elementary school teachers is an early milestone for learners to move to a higher school level, after elementary school.

\section{A. Performance}

Based on the above background, it can be said that performance is the result of work or output that can be quantity and quality. Reference [7] asserts that performance means both behavior and outcomes. The results in their right are the mental and physical products that are applied to the tasks. On the other hand, [46] states that staff performance leads to the conclusion that when managing the performance of teams and individuals it should first be taken into account regarding behavior (input) 
and output (output). This model is called a mixed model.

Teacher performance is to be improved, in accordance with the increase in compensation. Direct or indirect compensation greatly affects teacher performance. In this case, it is very important to state that well-regarded teachers feel valued by the government. Reference [19] states that an employee (teacher) is adequately compensated for his efforts and training is really encouraging for greater performance.

Training for teachers will enhance the ability and character development. This is consistent with the results of research in Kumbaya-Kyabakuza Division in particular and Uganda in general, which is similar to the findings of [47] in Ghana which concludes that the teacher's morale is very high.

Therefore, if teachers are involved in the right decision-making processes, and be able to reflect and change their situation (primary school students), they must have the skills necessary to in still the appropriate knowledge and manage their abilities in the classroom and understand their role in the community large. Usually, they are highly motivated and student achievement tends to increase.

Along with the improvement of teacher performance should be balanced also with the development of professional attitude sustainable. The need for training improved teachers' capacity and development. And this process should continue to be done because the development and improvement of teachers' ability is a process. This is in accordance with the results of research [30], in Nigeria that pays benefits and some non-financial rewards from employee recognition and conducive employment will improve employee performance positively and significantly related to teacher performance. While on the other hand, [9] describes the performance differences of employees of the organization. When conceptualizing an employee's performance, one must first distinguish between the behavioral aspects of the action and the aspects of the performance outcome.

\section{B. Compensation}

Compensation is the output and the benefit that employee receives the monetary exchange for the employee's to increase the performance [30]. In many sectors, pay-based performance improves business, output, and more, while the desired result is. However, compensation schemes for teacher salaries are often criticized for their poor performance. While in the other sector, reference [17], [26] concluded that wage incentives increase the worker and employee output by aligning the interests of workers and employers, providing information on the most valuable aspects of employee work, and motivating workers to give maximum effort.

While the results of the study [18] shows evidence from Israel and India that shows that teachers' structured salary incentives with the right program can be beneficial to students. However, despite expenses greater than $\$ 40$ million, in the first 2 years, NYC bonus programs did not improve student achievement. While [22] concludes that it is consistent with the prediction that group-based incentives are facilitated by the potential for free rises when payments depend on the actions of a large number of workers.

Some features of the education sector make it difficult to pay for teacher performance. First, pay performance is most effective when the entrepreneur can measure the output of the worker or if the effort and productivity are observed very closely. Expensive teacher monitoring and measuring individual teacher contributions to student achievement are difficult. Secondly, although education is complex and teachers should allocate their efforts to some activities, while teacher salary incentives are often linked to single performance measures (eg, student test scores), which can lead teachers to strive for more useful classroom activities [22].

Although on the other hand, [36] found that financial rewards are not the most motivating factor and financial incentives have a de-motivating effect among employees. Reference [28] stresses the financial incentives were very effective in motivating employees. Similarly, [34] concludes that financial incentives (the dimensions of pay satisfaction) have a significant effect on employee performance. However, it is important to note that in applying financial and non-financial rewards to 
workers, effective managers must understand the problem as a matter of need.

\section{Work Environment}

The work environment is the whole tooling and material tools encountered in the surrounding environment where a person works, as well as the arrangement of his work either as an individual or as a group [42]. Someone who works as a teacher let alone in primary school must know the school environment. Schools provide a natural environment for children to learn and practice a variety of skills. The experience of students in social interaction at school provides an important thing for future leaders. Students who become leaders in the classroom can have a strong influence on classroom and school life. School tasks facilitate the students' need to become a leader.

The atmosphere or climate in the classroom where students tend to feel more comfortable and better to optimize their learning opportunities given by teachers during their first year at school [5] and in their childhood [32]. Previous research on children has been identified as a leader by colleagues, teachers, or observers who have several characteristics. Most of these children are socially popular: their peers choose them as friends [10], [21], [18].

Thus, child leaders also tend to be very friendly and popular, the leadership qualities that teachers identify children in primary school, and this study also examines the socio-emotional characteristics of these children [10]. A conducive working environment is at the heart of nonfinancial rewards for employees (teachers). It has long been recognized by private sector employees and the public sector. According [3], a conducive working environment is usually the workplace of office staff and staff activities, organizationally.

\section{Motivation}

Motivation is a term used to describe such processes, both instinctively and rationally, in which people seek to satisfy their basic needs, perceived needs and personal goals can trigger performance [11]. While [32] defines motivation as a socially studied social behavior pattern that grants situations, needs, desires, mechanisms, and outcomes. However, on the other hand [41] states that motivation is a human psychological characteristic that contributes to one's level of commitment. Employee motivation is critical to the organizational effectiveness and is a performance predictor.

Teachers are assessed for their professional competence. In the teaching profession, teacher positions give them recognition of their abilities and achievements. While the power of recognition can give an impetus to employees in the community, the effects are not measurable on their own without paying something. Intrinsic rewards and extrinsic rewards are usually correlated. However, it does not directly show the relationship between the admiration of the workers and their willingness to work if their salary is not good enough.

Therefore there is no value of intrinsic rewards such as acknowledgment, admiration, and authorization when there is no extrinsic reward [21]. Teacher's motivation relates to goals and behaviors, performance and attitudes directed towards job goals [35].

Intrinsic motivation is defined as the doing of an activity for its inherent satisfaction rather than for some separable consequence. When intrinsically motivated, a person is moved to act for external challenges, pressures or rewards [37]. Intrinsic motivation refers to motivation to engage in the activity because it is fun and satisfying to do. Intrinsic motivation is based on the innate need for competence and self-determination. They hypothesize that when people are free to choose activities, they will look for interesting situations where they can rise to the challenge of promising activities.

The entire construct of intrinsic motivation illustrates the natural tendency for assimilation, mastery, spontaneous interest, and exploration that is essential for cognitive and social development. And that is the main source of pleasure throughout life [12]. This is because humans are freely endowed with intrinsic motivation. Intrinsic rewards produce the great performance. This embedded award creates a good role model and communication standard.

Extrinsic motivation rewards can be attributed to extrinsic motivation. This motivation is caused by the external factor that is financed. Incentives and 
rewards have become a subject of debate, whether they really employ employees or simply move them to work. If teachers are satisfied then they should be committed and engaged in their work [43]. Stress work, unfriendly, incompetence in the classroom and not conducive to work, this condition can be a growing problem for teachers to remain motivated in the teaching profession [15].

Skilled employee skills become inadequate, if they are not motivated to perform well in their work. When appropriate psychological states are provided to employees, it helps to improve the work of high motivation and job satisfaction, and this parameter depends on job characteristics. Motivate employees or simply move them to work. Reference [37] argues that extrinsic motivation is the achievement of a separate outcome from the performance. Extrinsic motivation encourages staff to complete their tasks in order to receive rewards. In another environment, awards motivate people to do so. These factors have conducted on the influence of intrinsic and extrinsic motivation factors to assess teacher performance. The dimension to intrinsic motivation is satisfaction derived from teaching, recognition, enjoyment of teaching, career development, challenging nature and competitive teaching, teaching as a goal in life and control over others. On the other hand, extrinsic motivation mainly includes awards that are applied externally as salary or wages, free accommodation, educational progress in paying premiums, meals, additional payments in case of financial problems, paid leave and free medical assistance. The existing literature has identified key influencing factors such as working conditions, administrative support and student behavior affecting teacher performance and teacher retention.

\section{METHODS}

This research uses descriptive correlation design. The descriptive section presents the characteristics of teachers, as well as their performance appraisal on different aspects of age and length of work. Correlation is used to find out the relationship variable dependent (performance) and independent (compensation, work environment, work motivation). The number of samples in this study is 88 teachers. Data were obtained by spreading the questionnaire and then analyzed using multiple linear regression.

Indicator for performance is quality and quantity of work, discipline, cooperation, creativity, personality. Indicator compensation is salary, allowance, insurance, award charter, promotion. Indicator work environment is the work structure, work responsibilities, attention and support leaders, inter-group cooperation, communication smoothness [42]. Job motivation Indicator is salary, supervision, policy and administration, working relationship, responsibility, [42]

Data collection techniques used were obtained by way of questionnaires, interviews, and observations. Questionnaires with the closed answer with answer choices from 1 to 5 . In this research used a Likert scale, with confidence level $5 \%$.

\section{RESULTS}

Table I shows that the age of productive teachers between the ages of 31 years - 35 years is $22.7 \%$ and aged between 36 years -51 years 35 by $64.8 \%$. The age of the teacher relatively young in educating students are the elementary school. However, with the level of education, skills and knowledge possessed, these elementary school teachers can work well and have high performance. The results of this study are consistent with the results of the study [44] that most 31-40-year old teachers in the Cotabato City Division perform high performance. It can be said that in terms of age, the two studies have many similarities.

\begin{tabular}{|c|c|c|c|}
\multicolumn{2}{c}{ ChARACTERISTICS OF RESPONDENTS By AGE } \\
\hline \multirow{2}{*}{ No } & \multirow{2}{*}{ Age } & \multicolumn{2}{c|}{ Total } \\
\cline { 3 - 4 } & & Frequency & Percentage \\
\hline. & $26-30$ & 11 & $12,5 \%$ \\
\hline 2. & $31-35$ & 20 & $22,7 \%$ \\
\hline 3. & $36-40$ & 22 & $25 \%$ \\
\hline 4. & $46-50$ & 10 & $11,4 \%$ \\
\hline 5. & 51 up & 25 & $28,4 \%$ \\
\hline & Total & 88 & $100 \%$ \\
\hline
\end{tabular}

Source: Primary data questionnaire. 
TABLE II

CHARACTERISTICS OF RESPONDENTS BASED GENDER

\begin{tabular}{|l|c|c|}
\hline \multirow{2}{*}{\multicolumn{1}{c|}{ Gender }} & \multicolumn{2}{c|}{ Total } \\
\cline { 2 - 3 } & Frequency & Percentage \% \\
\hline Female & 56 & $63,6 \%$ \\
\hline Male & 32 & $36,4 \%$ \\
\hline Total & 88 & $100 \%$ \\
\hline
\end{tabular}

Source: Primary data questionnaire.

TABLE III

CHARACTERISTICS OF RESPONDENTS BY EDUCATION

\begin{tabular}{|l|c|c|c|}
\hline \multirow{2}{*}{ No } & \multirow{2}{*}{ Education } & \multicolumn{2}{|c|}{ Total } \\
\cline { 3 - 4 } & & Frequency & Percentage\% \\
\hline 1. & S1 & 86 & $98 \%$ \\
\hline 2. & S2 & 2 & $2 \%$ \\
\hline \multicolumn{3}{|c|}{ Total } & 88 \\
\hline
\end{tabular}

Source: Primary data (Questionnaire), processed (2016)

TABLE IV

MULTIPLE LINEAR REGRESSION TEST RESULTS

\begin{tabular}{|c|c|c|c|c|}
\hline & $\begin{array}{l}\text { Regression } \\
\text { coefficients }\end{array}$ & $\mathbf{T}-$ counting & Sig & $\begin{array}{l}\text { Inform } \\
\text { ation }\end{array}$ \\
\hline (Constant) & 4.837 & 2.093 & 0.039 & $\begin{array}{l}\text { Signific } \\
\text { ant }\end{array}$ \\
\hline $\begin{array}{l}\text { Compensati } \\
\text { on (X1) }\end{array}$ & 0.217 & 2.173 & 0.033 & $\begin{array}{l}\text { Signific } \\
\text { ant }\end{array}$ \\
\hline $\begin{array}{l}\text { Work } \\
\text { Environmen } \\
\mathrm{t}(\mathrm{X} 2)\end{array}$ & 0.311 & 5.177 & 0.000 & $\begin{array}{l}\text { Signific } \\
\text { ant }\end{array}$ \\
\hline $\begin{array}{l}\text { Motivation } \\
\text { (X3) }\end{array}$ & 0.264 & 3.807 & 0.000 & $\begin{array}{l}\text { Signific } \\
\text { ant }\end{array}$ \\
\hline \multicolumn{2}{|l|}{$\mathrm{R}=0.700$} & $\mathrm{t}$ table & \multicolumn{2}{|l|}{$=1,99$} \\
\hline \multicolumn{2}{|c|}{ R Square $=0,489$} & F table & \multicolumn{2}{|l|}{$=2,71$} \\
\hline \multicolumn{2}{|c|}{$\begin{array}{l}\text { Adjusted R Square } \\
\left(\mathrm{R}^{2}\right)=0,471\end{array}$} & Sig. F & \multicolumn{2}{|l|}{$=0,000$} \\
\hline \multicolumn{2}{|c|}{ Durbin-Watson $=1,505$} & \multicolumn{3}{|c|}{$\mathrm{f}_{\text {count }}=26.841$} \\
\hline
\end{tabular}

Table II shows that the respondents in this study were $63.6 \%$ were female and $36.4 \%$ were male. Thus it can be said that elementary school teachers in West Balikpapan area are dominated by female teachers. The results of this study have similarities with the results of research [44] in the Cotabato City Division is a female teacher. So it can be said that both of these studies concluded the same findings that elementary school teachers in West Balikpapan neighbourhood dominated by women.

Table III shows that elementary school teachers in West Balikpapan $98 \%$ have undergraduate degrees and $2 \%$ have master degrees and meet the criteria as primary school educators. With the level of education that undergraduate, teachers can provide the maximum learning, in accordance with the ability of elementary school students in the learning process. The results of this study have similarities with the results research [44] that teachers in the Cotabato City Division have held bachelor and master degrees.

Thus, it can be concluded that primary school teachers in the western Balikpapan area have met the criteria and are supposed to have high levels of performance.

Table IV shows the test results to predict how far the influence of compensation variable, work environment and work motivation on teacher performance, either simultaneously or partially.

The analysis (ANOVA) indicated that the influence of all variables i.e., compensation, work environment and motivation to teacher performance was significant 0.000 or less than $\mathrm{a}=0.05(<5 \%)$, with value $\mathrm{F}=26.841$, while value $\mathrm{df}=84$, $-\mathrm{F}$ approach that can be used (same as t-test) by looking at probability or significant level. Testing simultaneously (Test F) can use $\mathrm{F}$ counting and $\mathrm{F}$ table, that is $\mathrm{F}$ counting $=26.841$ bigger than $\mathrm{F}$ table $\mathrm{e}=2.71$. It can be concluded that the compensation, work environment and motivation simultaneously (together) have an influence on the performance of elementary school teachers in the area of SDN West Balikpapan.

Compensation has a positive and significant effect on the performance of civil servant teachers, this is evidenced by the value of $t$ count $2.173>t$ table 1.99. In accordance [30] provides their own support for the findings when they found that financial incentives (the dimension of payroll satisfaction) have a significant effect on employees. On the other hand, [36] finds that financial rewards are not the most motivating factor and Financial, is incentives have a de-motivating effect among employees. While [28] stressed that financial incentives are very effective in motivating employees.

The work environment has a positive and significant effect on the performance of elementary school teachers, as evidenced by $\mathrm{t}$ count $5.177>\mathrm{t}$ table 1.99.

Motivation has a positive and significant effect on the performance of elementary school teachers, this is evidenced by $t$ count $3.807>t$ table 1.99 . In 
accordance with the results research of [44] that the majority of teachers are somewhat satisfied with the following aspects: school policy, interpersonal, interpersonal relationships, opportunities for promotion and growth, working conditions, selfemployment, achievement, recognition, and responsibility.

The results of the SDN teacher's performance in this western Balikpapan that teachers have a high ranking performance in their competence that creates an environment that promotes justice, keeping the classroom environment safe and conducive to learning, communicating expectations higher learning to each learner, establishing and maintaining a consistent standard of learners' behavior and creating a healthy psychological climate for learning.

\section{DISCUSSION}

Technical analysis used to validate the results of research by using $F$ Test at the confidence level 95 $\mathrm{a}=0.05$ degree of freedom $(\mathrm{df} 2)=\mathrm{n} \mathrm{k}=88-3=85$, then obtained $\mathrm{F}$ table $=1.99$ and the simultaneous correlation (R) of $0.700 \mathrm{R}$ square of 0.489 and Adjust R Square 0.471, this means the contribution of compensation, work environment, work motivation to the performance of the highest elementary school teachers is $70 \%$.

Overall compensation, work environment, and work motivation partially indicate that the three independent variables have a significant influence on the performance of elementary school teachers in West Balikpapan area. And have a strong relationship. The results of this study have similarities with [22] that there is a strong relationship between the motivation and performance of teachers in Kenya who have a certificate of basic educators.

It is important to maintain quality and qualified teachers to provide high-quality education in schools [23].

Partial compensation contributes to the performance of West Balikpapan public elementary school teachers. However, other researchers argue differently for example empirically still lacking the empirical evidence demonstrated [40] asserts that nonfinancial rewards in Indonesia a conducive working environment could be a greater impact on job satisfaction and motivation than financial rewards. It is important to note that in applying the financial and non-financial rewards to the workers, effective managers must think as a matter of need. Compensation may reduce teachers' intentions to move to other schools, as many studies find that low salaries are the main predictor of teacher earnings [27]. Other studies recommend high teacher salaries as an effective strategy to reduce teacher income problems [31].

Partial working environment contributes to the performance of West Balikpapan public elementary school teachers. School facilities also include school buildings such as classrooms, libraries, laboratories, workshops, and libraries. And others include teaching aids, chairs, is tables. However, [2] argues that the quality of education has direct relevance to the availability or lack of physical facilities and the overall atmosphere. However, there are also schools according to [22] that teaching/ learning facilities in their schools are not enough. a comfortable working environment can ensure employees are eager to work [33]. This indicates that the employee has a big responsibility so that it can improve its performance. Employee delight and employee fit with company rules reflect a comfortable working environment. It can improve the employee's performance [34] this is because to achieve success an organization must answer the needs of employees, especially aspects of quality of work life and other factors that can impact on the performance of the work. Aspects of the quality work environment and other factors that can impact on employee performance. Environmental theory describes the relationship between the quality of work environment and performance. According to this theory, individual behavior is influenced by how one perceives and reacts to that environment. Partial compensation contributes to the performance of West Balikpapan public elementary school teachers. However, other researchers argue differently for example empirically still lacking the empirical evidence demonstrated [30] asserts that nonfinancial rewards in Indonesia a conducive working environment could be a greater impact on job satisfaction and motivation than financial 
rewards. It is important to note that in applying the financial and non-financial rewards to the workers, effective managers must think as a matter of need. Compensation may reduce teachers' intentions to move to other schools, as many studies find that low salaries are the main predictor of teacher earnings [17]. Other studies recommend high teacher salaries as an effective strategy to reduce teacher income problems [24]. This is confirmed in Vroom's expectation theory [44] that performance depends not only on the amount of effort given but also on the influence of the person's ability intervention and its nature. The relationship between effort and performance is mediated by the abilities and characteristics of the individual (including personality and competence). Thus, it can be said that the work environment affects the performance of public elementary school teachers in the western city of Balikpapan. This has been proven by some of the previous researchers on the work environment. Generally, social informationprocessing theory supports the idea that the environment does have an effect on attitudes, behaviors, and work and employee satisfaction that ultimately improve performance [1]. While the results aspect refers to the consequences and results of individual behavior and can be influenced by environmental factors [8].

The level of motivation is inherent in setting their own targets and trying to achieve them. Motivation is probably the most important factor that can be targeted by educators improving interdisciplinary theory learning has been widely postulated to explain motivation. While each of these theories has some truth, no single theory seems to adequately explain all human motivations. In accordance with McGregor's theory [41] work motivation is the assumption that people are not naturally lazy and just after work breaks. Therefore they exercise self-direction and control the commitment to the goals they have set themselves. Therefore, the head teachers of public elementary schools can effectively apply this theory in enabling teachers to share lessons democratically; can lead to the possibility of creating work environments that create high-motivation potential teachers for their own good, learners, and the whole school [33]. On the other hand, [30] concluded that the performance of elementary school teachers in Kimaanya Kyabakuza Division, Masaka district, showed that teacher performance was quite good despite the fact that their motivation was inadequate. Intrinsic Motivation. There is a positive significant correlation between intrinsic motivations on teacher performance. While not every teacher is motivated by the same factors, focusing on the list of motivating programs can help. Head teachers have plans that can cover everything from monetary incentives to rewards and recognition, development programs that support work-life balance, just to create a pleasant office environment [5]. On the other hand, master plays an important role in providing education to students. Therefore, every school is trying to recruit good people. And the qualified faculty is who can provide education qualified. Reference [29] argues that both intrinsic and extrinsic motivations lead the superior performance of teachers. Motivational factors such as benefits, salary and recognition and others have a positive impact on their satisfaction that also results in their effective performance. According to [6] facilities refer to the teacher's physical workplace and available resources. According to many studies, the facility has been linked to teacher career paths.

The term extrinsic motivation refers to the performance of an activity to achieve some segregated results and thus contrasts with the intrinsic motivation that refers to engaging in activities for the inherent satisfaction of the activity itself. Extrinsic motivation is the action taken to achieve it at the end of the instrumental, such as getting a reward or avoiding a punishment. This type of extrinsic motivation does not necessarily imply a reduction in self-esteem in the conduct.

\section{CONCLUSIONS}

Based on the results of research and discussion that the performance of civil servant teachers in the Regional Environment SDN West Balikpapan, it can be concluded that the independent variables that include compensation, work environment, and work motivation together significantly influence the performance of civil servant teachers in the Regional Environment SDN West Balikpapan. 
Partially proven to be true, that the compensation variables have a positive and significant effect; that the work environment variable has positive and significant effect; that the variable of Work Motivation has positive and significant influence. And work environment variables have a dominant influence on the Performance of civil servant teachers in the Regional Environment SDN West Balikpapan. However, ultimately it is only quality teaching and teacher commitment that can produce good student quality, contributing to the State of Indonesia especially the western Balikpapan area for the future.

Intrinsic and extrinsic motivation leads to superior performance of teachers. Motivational factors such as benefits, salary and recognition and others have a positive impact on their satisfaction that also results in their effective performance.

Human capital, especially teacher quality, is believed to be one of the most important inputs into education production. The teacher's contribution to producing good quality from students cannot be ignored. Thus it is important for every school to keep qualified teachers.

\section{REFERENCES}

[1].Aamodt, M. (2009). Industrial/Organizational Psychology. Belmont: CA.Cengage Learning.

[2]. Abrahams, M. (2003). Educational Administration in Nigeria. Nigeria, Port Harcout: Pam Unique Publisihing Company Limited.

[3]. Abu-Abdissamad, A M. (2013). Non-financial Reward System in Nigerian Public and Private Organizations. Internationals Journal or Research in Computer Application and Management, 3 (8): 32 - 36.

[4]. Bates, R A. and Holton, E F. (2010). Computerized Performance Monitoring: A Review of Human Resource Issue, Human resource Management Review, Winter, $267-288$.

[5]. Birch, S H. and Ladd, G W. (1996). Interpersonal relationships in the school environment and children's early school adjustment: The role of teachers and peers. in J, Juvonen. And K, R Wentzel. Social motivation, understanding children's school adjustment. New York: Cambridge University Press.

[6]. Boyd, D. Grossman, P. Ing, M. Lankford, H. Loeb, S. and Wyckoff, J. (2011). The influence of school administration on teacher retention decisions. American Educational Research Journal, 48 (2), 303-333.

[7]. Brumback, G.B. (2010). Some Ideas, Issues and Predictions about performance Management, Public Personnel Management, Winter, 387 402.

[8]. Campbell, J P. (1990). Modeling performance prediction problem in industrial and organizational psychology. In M, D Dunnette and L, M Hough. Handbook of Industrial and organizational psychology. Palo Alto: Consulting Psychologists Press.

[9]. Campbell, J P. McGloy, R A. Oppler, S H. and Sager, G E. (1993). A theory of performance. in N, Schmidt. W, G Borman and Associates, Personnel selection in organizations. San Fransisco, Jossey-Bass.

[10]. Chen, X. Rubin, K H. and Sun, Y. (1992). Social reputation and peer relationships in Chinese and Canadian children: A cross-cultural study. Child Development, 63, 1336-1343.

[11]. Cole, G.A. (1996). Management Theory and Practice, New Delhi: Martins.
[12]. Csikszentmihalyi, M. \& Rathunde, K. (1993). The measurement of flow in everyday life: Toward a theory of emergent motivation. in Ryan, R. M., \& Deci, E. (2000). Self-determination theory and the facilitation of intrinsic motivation, social development, and well being. American Psychologist, 55, 68-78.

[13]. Dodge, K. A. (1983). Behavioral antecedents of peer social status. Child Development, 54, 1386-1399.

[14].Ejumudo, K.B. 2014. Pay Reward System Management and Staff Performance in Nigeria: A Study of the Delta State Civil Service. Public policy and Administration Research, 4 (9): 79 -95.

[15]. Engelking, J.L. (1987). Attracting and retaining quality teachers through incentives. NASSP Bulletin. 71 (500), 1-8.

[16]. Fukada, H. Fukada, S., \& Hicks, J. (1997). The relationship between leadership and sociometric status among preschool children. The Journal of Genetic Psychology, 158, 481-486.

[17]. Gibbons, Robert. (1998). Incentives in organizations. Journal of Economic Perspectives, 12, (4), 115-132.

[18]. Goodman, Sarena and Lesley Turner. (2010). Teacher incentive pay and educational outcomes: evidence from the NYC bonus program. Working Paper no. 10-07, Program on Education Policy and Governance Working Paper Series, Cambridge, MA.

[19]. Gunu, U. (2005). Performance Management, in Topic in Modern Management. A publication of Department of Business Administration University of Ilorin.

[20]. Mertler, H. (1992). Value make the company. Harvard Business Review.

[21]. Hafiza, N S. Shah, S S., Jamsheed H. \& Zaman, K. (2011). Relationship Between Rewards And Employee's Motivation. Business Intelligence Journal, 327-334.

[22]. Holmstrom, Bengt and Paul Milgrom. (1991). Multitask principal-agent analyses: incentive contracts, asset ownership, and job design. Journal of Law, Economics, and Organization, 7 (January): 24-52.

[23]. Holt, Davis H. (1993). Management: Concept and Practices. New Jersey : Prentice Hall, Englewood Cliffs.

[24]. Ingersoll, R M. and Smith, T M. (2003). The wrong solution to the teacher shortage. Educational Leadership, 60 (8), 30-34.

[25]. Kiseesi, L M. (1998). Job Satisfaction among Support Staff of Makerere University Hall of Residence, Unpublished Thesis.

[26. Lazear, Edward P. (2003). Teacher incentives. Swedish Economic Policy Review, 10: 179-214.

[27]. Liu, X S. (2007). The Effect of teacher influence at school on first-years teacher attrition: a multilevel analysis of the schools and staffing survey form 1999-2000. Educational Research and Evaluation, 13 (1), 1-16.

[28]. Lotta, L. (2013). The Impact of Financial and nonfinancial Rewards on Employee Performance in Federal Parastatals. Journals of Management, (4) :29-38.

[29]. Marry, A. (2010). Motivation and the performance of primary school teachers in Uganda: A case of Kimaanya-Kyabankuza division Madaka District. Uganda, Makeerere University: unpublished Dissertation.

[30]. Mbah, Stella I. Mgbemena, Gabriel C. Ejike, Daniel C. (2015). Effective Reward Management and Employee Performance in Civil Service (A Study of anambra State Civil Service). European Journal of Business and Management, 7 (27).

[31]. Ukeje. (1992). The psychology and exposure to educational management Canada. Medical Publisher.

[32]. Ukeje. (1992). The psychology and exposure to educational management, Canada: Medical publishers.

[33]. Okeke, B S. (2002). Educational Administration and Management. The Nigerian Factors: Onitsha, Meks publisher.

[34]. Okumbe. (1988). Human Resource Management, An Educational Prospective. Nairobi.

[35]. Oyer, P. (2004), Why do firms use incentives that have no incentive effects? Journal of Finance, 59, 1619-1640.

[36]. Peretomode, V F. (1991). Educational administration, applied concepts and theoretical perspectives for students and practitioners. Lagos: JOJA Educational Research and Publishers Limited.

[37]. Perry, J L. (2006). Motivating Employees in a New Governance Era: the performance Paradigm Revisited. Public Administration Research, (66), $505-514$.

[38]. Ryan, R.M and Deci, E.L. (2000). Intrinsic and Extrinsic motivations: Classic definitions and new directions. Contemporary Educational Psychology, 25:54-67. 
[39]. Ryan, R M. and Deci, E. (1995). Psychological needs and the facilitation of integrative process. In Ryan, R M. and Deci, E. (2000), American Psychologists.

[40]. Ryan, R.M., \& Deci, E. (2000). Self-determination theory and the facilitation of intrinsic motivation, social development, and well being. American Psychologist, 55, 68-78.

[41]. Scharf, M. \& Hertz-Lazarowitz, R. (2003). Social networks in the school context: effects of culture and gender. Journal of Social and Personal Relationships, 20, 843-858.

[41]. Shiley, S. (2006). Motivation and Management Style in the Public and Private Sectors in Taiwan and a Comparison with United State. Journal of Applied Social Psychology, 26 (20), 1827-1837.

[42]. Suryadi, A. \& Rosyidi, H. (2013). Kinerja karyawan ditinjau dari analisis faktor budaya perusahaan. Jurnal Penelitian Psikologi, 4 (2), 166-180.
[43]. Tanja, Sargent \& Emily, Hannum. (2005). Keeping Teachers Happy: Job Satisfaction among Primary School Teachers in Rural Northwest China. University of Pennsylvania.

[44].Usop, Annierah Maulana. (2013). Work Performance and Job Satisfaction among Teachers. International Journal of Humanities and Social Science, 3 (5).

[45]. Vroom, V.H. (1964). Work and Motivation. New York, Wiley.

[46]. Hartley, Sigan L. Erin, T. Barker, and Marsha, Mailick Seltzer, Frank, Floyd. Jan, Greenberg. Gael, Orsmond. and Daniel, Bolt. (2010). The Relative Risk and Timing of Divorce in Families of Children With an Autism Spectrum Disorder. Journal of Family Psychology, 24 (4), 449457. 